\title{
PENGARUH MOTIVASI BELAJAR DITINJAU DARI LATAR BELAKANG PILIHAN JURUSAN TERHADAP KEMAMPUAN BERPIKIR KRITIS MAHASISWA DI STKIP SILIWANGI BANDUNG
}

\author{
Luvy Sylviana Zanthy \\ Program Studi Pendidikan Matematika, FKIP, STKIP Siliwangi Bandung, \\ Jln. Terusan Jenderal Sudirman, Cimahi, 40526, Indonesia \\ e-mail: lszanthy@gmail.com
}

\begin{abstract}
Abstrak. Penelitian ini bertujuan untuk mengetahui pengaruh motivasi belajar ditinjau dari latar belakang pilihanjurusan terhadap kemampuan berpikir kritis mahasiswa di STKIP Siliwangi Bandung. Populasi dalam penelitian ini adalah seluruh mahasiswa Program Studi Pendidikan Matematika di STKIP Siliwangi. Sedangkan sampelnya adalah 2 kelas Program Studi Pendidikan Matematika yang sedang menempuh mata kuliah Struktur Aljabar II. Pengujian hipotesis ini menggunakan anova 1 jalur. Hasil penelitian ini menunjukkan bahwa:1)Terdapat pengaruh motivasi belajar mahasiswa ditinjau dari latar belakang pilihan jurusan terhadap kemampuan berpikir kritis matematis mahasiswa di STKIP Siliwangi Bandung pada Mata Kuliah Struktur Aljabar II; 2) Besarnya pengaruh motivasi belajar motivasi belajar mahasiswa ditinjau dari latar belakang pilihan jurusan terhadap Kemampuan berpikir kritis mahasiswa pada mata kuliah Struktur Aljabar II sebesar 48,297 sedangkan sisanya sebesar 51,703 dipengaruhi oleh faktor-faktor lain.
\end{abstract}

Kata kunci: Motivasi belajar, Latar belakang jurusan, Kemampuan berpikir kritis

\section{PENDAHULUAN}

Pendidikan merupakan salah satu andalan suatu bangsa untuk mempersiapkan sumber daya manusia yang dibutuhkan untuk menghadapi tantangan zaman. Persiapan sumber daya manusia dalam bidang pendidikan ini harus dilakukan sejak dari masa pendidikan dasar, menengah dan tinggi.

Berbicara tentang tantangan dan permasalahan pendidikan di Indonesia, maka perlu dipersiapkan kegiatan pendidikan yang mampu membekali peserta didik dalam menghadapi tantangan hidup di masa depan, yaitu menyelenggarakan pendidikan yang tanggap terhadap tantangan era globalisasi. Guru sebagai pendidik dituntut untuk selalu mengembangkan proses pembelajaran agar sesuai dengan kondisi dan zaman sekarang.
Salah satu kecakapan hidup (lifeskill) yang perlu dikembangkan melalui proses pendidikan adalah keterampilan berpikir (Depdiknas, 2002), karena kemampuan seseorang untuk dapat berhasil dalam kehidupannya antara lain ditentukan oleh keterampilan berpikirnya, terutama dalam upayamemecahkan masalah-masalah dalam kehidupan yang dihadapi.

Matematika merupakan salah satu pelajaran yang penting, karena selain dituntut kemampuan berpikir seseorang, banyak masalah dalam kehidupan yang dapat disajikan ke dalam model matematika. Dengan mempelajari matematika, seseorang terbiasa berpikir secara sistematis, ilmiah, menggunakan logika, kritis, serta dapat meningkatkan daya kreativitasnya. Ruseffendi (2006) menyatakan bahwa matematika itu penting baik sebagai alat bantu, sebagai ilmu (bagi 
ilmuwan), sebagai pembimbing pola pikir maupun sebagai pembentuk sikap.

Dalam pembelajaran matematika, seorang dosen hendaknya tidak menyekat secara ekstrim pelajaran matematika sebagai penyajian materi-materi matematika belaka. Topik-topik dalam matematika sebaiknya tidak disajikan sebagai materi secara parsial, tetapi sebaiknya diintegrasikan antara satu topik dengan topik yang lainnya, bahkan dengan bidang lain. Matematika harus diperkenalkan dan disajikan kedalam kehidupan kita. Menyajikan matematika hanya sebagai kumpulan fakta-fakta saja tidak akan menumbuhkan kebermaknaan dan hakikat matematika sebagai queen of thesciencedan sebagai pelayan bagi ilmu lain.

Struktur Aljabar II merupakan salah satu mata kuliah yang dirasa sulit untuk dipelajari karena materi yang disajikan lebih bersifat abstrak. Dalam mempelajari Struktur Aljabar II, mahasiswa membutuhkan kemampuan-kemampuan matematis, diantaranya adalah kemampuan berpikir kritis. Dalam mata kuliah tersebut, mahasiswa dituntut untuk peka terhadap situasi yang sedang dihadapi,mampu mengkritisi alur analisis terhadap definisi, teorema dan pembuktian aljabar, sehingga diharapkan dapat sejalan dengan terasahnya kemampuan berpikir kritis matematis mahasiswa.

Salah satu cara untuk meningkatkan kemampuan berfikir kritis mahasiswa adalah adanya motivasi yang baik dalam belajar dalam dirinya, karena dengan adanya motivasi seseorang siswa secara sadar dan niat akan tergerak atau terdorong untuk melakukan aktivitas-aktivitas belajar dengan mengarahkan segala daya dan upaya untuk mencapai tujuan yang di inginkannya dalam hal ini hasil siswa dapat berpikir kritis. Hal ini sejalan dengan apa yang diungkapkan olehMc. Donald (dalam Sardiman, 2007) bahwa motivasi adalah perubahan energi dalam diri seseorang yang ditandai dengan munculnya feelingdan didahului dengan tanggapan terhadap adanya tujuan.

Motivasi belajar setiap orang berbeda, berbagai macam latar belakang jurusan di sekolah (IPA, IPS, Bahasa dan Kejuruan) dapat mengakibatkanperbedaan persepsi mahasiswa dalam menyerap mata kuliah. Perbedaan persepsi tentang mata kuliah ini tentunya akan menimbulkan motivasi belajar dan kemampuab berpikir kritis yang berbeda pula pada masingmasing mahasiswa.

Pendapat di atas dikuatkan oleh penelitian yang dilakukan oleh Mayadiana (dalam Fachurazi, 2011) yang berjudul Pembelajaran dengan Pendekatan Diskursif untuk Mengembangkan Kemampuan Berpikir Kritis Mahasiswa PGSD, bahwa kemampuan berpikir kritis mahasiswa calon guru SD masih rendah, yakni mencapai $36,62 \%$ untuk mahasiswa berlatar belakang IPA, 26,62\% untuk mahasiswa berlatar belakang Non-IPA, serta 34,06\% untuk keseluruhan mahasiswa. Sama halnya dengan hasil penelitian Maulana (dalam Fachrurazi, 2011) yang berjudul Pendekatan Metakognitif sebagai Alternatif Pembelajaran Matematika untuk Meningkatkan Kemampuan Berpikir Kritis Mahasiswa PGSD, bahwa rerata kemampuan berpikir kritis mahasiswa calon guru SD sebesar 33,3\%.

Penelitian ini bertujuan untuk mengetahui pengaruh antara motivasi belajar ditinjau dari latar belakang pilihan jurusan (IPA, IPS dan Kejuruan) terhadap kemampuan berpikir kritis mahasiswa di STKIP Siliwangi Bandung pada Mata Kuliah Struktur Aljabar II dan untuk mengetahui besar pengaruh motivasi belajar terhadap kemampuan berpikir kritis matematis ditinjau latar Belakang Jurusan (IPA, IPS dan Kejuruan) mahasiswa di STKIP Siliwangi Bandung pada Mata Kuliah Struktur Aljabar II.

\section{PENGERTIAN MOTIVASI}

Motivasi ialah suatu proses untuk menggalakkan sesuatu tingkah laku supaya 
dapat mencapai matlumat-matlumat yang tertentu. Konsep motivasi memang susah dipahami karena kesannya tidak dapat diketahui secara langsung. Purwanto (2002) mengemukakan bahwa istilah motivasi adalah "pendorongan" suatu usaha yang disadari untuk mempengaruhi tingkah laku seseorang agar ia tergerak hatinya untuk bertindak melakukan sesuatu sehingga mencapai hasil atau tujuan tertentu.

Motivasi mengandung tiga komponen pokok, yaitu menggerakan, mengarahkan, dan menopang tingkah laku manusia yaitu (a) Menggerakan berarti menimbulkan kekuatan pada individu, memimpin seseorang untuk bertindak dengan cara tertentu. Misalnya kekuatan dalam hal ingatan, respon-respon efektif, dan kecenderungan mendapat kan kesenangan. (b) Mengarahkan atau menyalurkan tingkah laku. Dengan demikian ia menyediakan suatu orientasi tujuan. Tingkah laku individu diarahkan terhadap sesuatu. (c) Untuk menjaga atau menopang tingkah laku, lingkungan sekitar harus menguatkan intensitas dan arah dorongan-dorongan dan kekuatan-kekuatan individu.

Motivasi dapat didefinisikan sebagai kekuatan-kekuatan yang kompleks, dorongan-dorongan,kebutuhan-kebutuhan, pernyataan-pernyataan, atau mekanismemekanisme lainnya yang memulai dan menjaga kegiatan-kegiatan yang inginkan ke arah penciptaan tujuan-tujuan personal.

Motivasi memang muncul dari dalam diri manusia, tetapi munculnya karena terangsang/terdorong oleh adanya unsur lain, dalam hal ini adalah tujuan. Tujuan ini akan menyangkut soal kebutuhan. Motivasi dapat juga dikatakan serangkaian usaha untuk menyediakan kondisi-kondisi tertentu, sehingga orang tersebut mau dan ingin melakukan sesuatu, dan bila dia tidak suka, maka dia akan berusaha untuk meniadakan atau mengelakkan perasaan tidak suka itu. Jadi motivasi itu dapat dirangsang oleh faktor dari luar tetapi motivasi itu adalah tumbuh di dalam diri seseorang.

\section{JURUSAN DI SEKOLAH MENENGAH}

Latar belakang jurusan mahasiswa sebelum memasuki jenjang perguruan tinggi (PT) juga akan berpengaruh terhadap hasil belajarnya di perguruan tinggi. Pengertian latar belakang jurusan pada penelitian ini adalah mahasiswa yang berlatar belakang sekolah dari SMA jurusan IPA, IPS dan Bahasa serta mahasiswa yang berlatar belakang sekolah SMK (Kejuruan). Hal ini sesuai dengan SisdiknasNo 20 Tahun 2003 Bab VI Pasal 18 Ayat 2 yang berbunyi: Pendidikan menengah terdiri atas pendidikan menengah umum dan pendidikan menengah kejuruan dan ayat 3 yang berbunyi: Pendidikan menengah berbentuk sekolah menengah atas (SMA), madrasah aliyah (MA), sekolah menengah kejuruan (SMK), dan madrasah aliyah kejuruan (MAK), atau bentuk lain yang sederajat.

\section{KEMAMPUAN BERPIKIR KRITIS}

Berpikir matematis merupakan pelaksanaan kegiatan atau proses matematik (doingmath) atau tugas matematika (mathematicaltask). Proses berpikir matematis, sebagaimana yang digambarkan oleh Marpaung dalam Mudrikah (2006) merupakan proses yang dimulai dari penemuan informasi, pengolahan, penyimpanan, dan memanggil kembali informasi tersebut dari ingatan.

Menurut Ennis (dalam Fisher, 2001), berpikir kritis adalah berpikir reflektif dan beralasan (masuk akal) dengan menekankan pada pembuatan keputusan tentang apa yang harus dipercayai atau dilakukan. Reflektif artinya mempertimbangkan atau memikirkan kembali segala sesuatu yang dihadapinya sebelum mengambil keputusan. Beralasan (masuk akal) artinya memiliki keyakinan dan pandangan yang didukung oleh bukti yang tepat, actual, cukup dan relevan. 
Shlecht dan Ennis (dalam Splitter,
1991) mendefinisikan keterampilan berpikir kritis berdasarkan pandangan psikologis dan pandangan fisiologis. Pandangan psikologis menyatakan bahwa : 1) Kemampuan berpikir kritis adalah segala keterampilan yang diperlukan untuk mengenal, menganalisis, dan mengevaluasi argumen. 2) Keterampilan berpikir kritis adalah kemampuan bernalar dan berpikir reflektif yang difokuskan untuk memutuskan hal-hal yang diyakini akan dilakukan. 3) Kemampuan berpikir kritis adalah proses-proses mental, strategi dan representasi yang memungkinkan penyelesaian masalah, membuat keputusan dan belajar konsep-konsep baru.

Dengan demikian, seorang yang berpikir kritis adalah seseorang yang mampu menyelesaikan masalah, membuat keputusan dan belajar konsep-konsep baru melalui kemampuan bernalar dan berpikir reflektif berdasarkan sesuatu yang diyakini benar.

Menurut Glaser (dalam Fisher, 2001)terdapat beberapa keterampilan (kompetensi-kompetensi dasar) yang mendasari berpikir kritis, yaitu : 1) mengenal berbagai masalah; 2) menemukan sarana agar dapat dilaksanakan pada masalah tersebut; 3) mengumpulkan fakta-fakta informasi yang berkaitan; 4) mengenal asumsi-asumsi dan nilai yang tidak dinyatakan; 5) memahami dan menggunakan bahasa dengan ketelitian, kejelasan, dan diskriminasi; 6) menginterpretasikan data; 7) menilai faktafakta dan mengevaluasi pernyataan; 8) mengenal keberadaan hubungan yang logis antara proposisi-proposisi; 9) menarik kesimpulan-kesimpulan dan generalisasigeneralisasi yang terjamin; 10) menguraikan tes pada generalisasi dan kesimpulan yang muncul; merekonstruksikan pola-pola keyakinan seseorang berdasarkan pada pengalaman yang lebih luas; dan 12) membuat keputusan-keputusan yang tepat mengenai hal-hal yang tepat mengenai hal-hal dan kualitas-kualitas khusus dalam kehidupan sehari-hari.

Menurut Glazer (dalam Runisah, 2008), bahwa yang dimaksud dengan berpikir kritis matematis adalah kemampuan dan disposisi untuk melibatkan pengetahuan sebelumnya, penalaran matematis, dan strategi kognitif untuk menggeneralisasikan, membuktikan, atau mengevaluasi situasi matematis yang kurang dikenal dalam cara yang reflektif. Menurut Innabi (dalam Hendrayana, 2008), bahwa indikator-indikator yang dapat mengukur berpikir kritis dalam matematika adalah indikator yang telah dikemukakan oleh Ennis, yaitu konsep, generalisasi, keterampilan dan pemecahan masalah.

Berpikir kritis sangat diperlukan oleh setiap orang untuk menyikapi berbagai permasalahan dalam realita kehidupan, dengan berpikir kritis seseorang dapat mengatur, menyesuaikan, atau mengubah pola pikirnya, sehingga dapat memutuskan suatu tindakan yang tepat. Seseorang yang berpikir kritis adalah orang yang terampil dalam bernalar, dan memiliki kecenderungan untuk mempercayai dan bertindak sesuai dengan penalarannya. Seseorang mempunyai kemampuan berpikir kritis apabila ia mempunyai kemampuan dalam menganalisa, membuktikan berdasarkan alasan yang telah dipertimbangkan secara rasional, membuat generalisasi dari data yang ada, serta memberikan penilaian tentang kecukupan argument, data, dan kesimpulan.

Berdasarkan uraian yang telah dikemukakan maka kemampuan berpikir kritis yang digunakan dalam penelitian ini adalah terdiri atas lima fase, yaitu memicu kejadian (Triggerevent), eksplorasi, menarik kesimpulan, klarifikasi, dan resolusi. Triggerevent, yaitu kemampuan mengidentifikasi kelengkapan premis suatu pernyataan, konsep-konsep yang dibutuhkan dalam membuktikan suatu pernyataan. Eksplorasi, yaitu kemampuan mengkonstruksi makna/arti, menyelidiki 
ide matematik. Menarik kesimpulan yaitu kemampuan membuat dan memutuskan ide matematik secara induktif atau deduktif. Klarifikasi, yaitu kemampuan mengevaluasi dan menjelaskan, menentukan konteks ide matematik. Resolusi, yaitu kemampuan mengusulkan / memperbaiki langkah-langkah bukti suatu pernyataan matematik.

Kemampuan berpikir kritis dapat terlatih bila kemampuan itu diterapkan dalam situasi diskusi di kelas yang membahas konsep matematika tertentu. Dalam diskusi tersebut antar mahasiswa beradu argumentasi secara rasional. Jika dalam proses pembelajaran seorang dosen selalu berupaya melatih mahasiswanya untuk berpikir kritis maka out-put pembelajaran menghasilkan mahasiswamahasiswa pemikir kritis yang baik.

Baked (2004) mengemukakan lima komponen dalam berpikir kritis yang baik, yaitu (1) Skillful (terampil), menerapkan ketrampilan dalam bentuk proses berpikir; (2) Responsible (dapat dipertanggungjawabkan), berpikir kritis merupakan tindakan publik, bukan tindakan pribadi. Argumentasi yang dikemukakan berperan untuk suatu diskursus; (3) Berdasarkan kriteria untuk membuat keputusan, seorang pemikir kritis yang baik berpikir dengan tegas mengapa dia menarik kesimpulannya dan memeriksa penalaran untuk kesimpulannya. Dengan demikian seorang pemikir kritis tidak hanya melihat apa yang dipertimbangkan tetapi ia juga melihat mengapa kita mengambil kesimpulan tersebut; (4) Mengembangkan presentasi yang sensitif ke konteks, respek terhadap cara-cara di dalam bidang tertentu dan disesuaikan dengan kesimpulan di dalam bidang tersebut, dan (5) Self-correcting (koreksi diri), seorang pemikir kritis yang baik secara konstan berusaha untuk meningkatkan berpikirnya, seperti memonitor proses berpikir, menggunakan umpan balik, dan internalisasi kemampuan kritik

\section{METODE PENELITIAN}

Jenis penelitian yang digunakan dalam penelitian ini adalah penelitian kuantitatif yang menggunakan pendekatan expostfacto, yaitu penelitian yang melakukan kajian mengenai pengaruh variabel bebas yaitu Motivasi Belajar $\left(X_{1}\right)$, Latar belakang pilihan jurusan $\left(X_{2}\right)$, Struktur Aljabar II $\left(X_{3}\right)$ terhadap Kemampuan Berpikir KritisMatematis (Y) sebagai variabel terikat, sedangkan variabel kontrol dalam penelitian ini adalah angket motivasi belajar sebagai perangkat yang digunakan untuk mengambil nilai motivasi mahasiswa.

Teknik pengumpulan data dalam penelitian ini adalah metode angket/kuesioner dan metode dokumentasi, sedangkan instrumen dalam penelitian ini adalah angket motivasi belajar siswa dan skor kemampuan berpikir kritis mahasiswa.

\section{HASIL DAN PEMBAHASAN}

Penelitian ini dilakukan sejak tanggal 5 September 2015 dan berakhir pada tanggal 17 Oktober 2015 dilaksanakan di STKIP Siliwangi pada perkuliahan kelas non reguler pada mata kuliah Struktur Aljabar II. Kemudian dilanjutkan dengan proses analisis data menggunakan bantuan Microsoft Excel 2007 dan SPSS 22.0.

Data yang diolah diperoleh dari hasil pengisian angket tertutup tentang motivasi mahasiswa berdasarkan latar belakang jurusan ketika di Sekolah Menengah (IPA, IPS dan Kejuruan). Angket juga memuat pernyataan-pernyataan dengan jawaban sangat setuju, setuju, netral, tidak setuju dan sangat tidak setuju yang harus dipilih mahasiswa sesuai keadaan sebenarnya yang dialami. Kemudian, data tes kemampuan berpikir kritis matematis mahasiswa pada mata kuliah Struktur Aljabar II dengan skor maksimal 16. 
Analisis Pengaruh Motivasi Belajar dengan Kemampuan Berpikir Kritis Matematis Mahasiswa

Analisis pengaruh motivasi belajar dengan kemampuan berpikir kritis matematis mahasiswa dilakukan untuk mengetahui ada atau tidaknya pengaruh antara motivasi belajar dengan kemampuan berpikir kritis matematis mahasiswa. Analisis dilakukan menggunakan rumus regresi sederhana.

Hipotesis penelitian dirumuskan sebagai berikut:

$H_{0}$ : Terdapat pengaruh yang signifikan antara motivasi belajar dengan kemampuan berpikir kritis matematis mahasiswa pada Mata Kuliah Struktur Aljabar II

$H_{1}$ : Tidak Terdapat pengaruh yang signifikan antara motivasi belajar dengan kemampuan berpikir kritis matematis mahasiswa pada Mata Kuliah Struktur Aljabar II

Berdasarkan uji pengaruh motivasi belajar terhadap kemampuan berpikir kritis matematis pada mata kuliah Struktur Aljabar II pada Tabel 1. di bawah ini, diperoleh nilai signifikansi sebesar 0,047 $<0,05$, ini menunjukkan bahwa $\mathrm{H}_{0}$ diterima, sehingga diperoleh interpretasi bahwa terdapat pengaruh yang signifikan antara motivasi belajar dengan kemampuan berpikir kritis matematis mahasiswa pada Mata Kuliah Struktur Aljabar II.

Dengan taraf signifikansi $\alpha=0,05$ diperoleh data sebagai berikut:

Tabel 1. Hasil Uji Korelasi

TOTAL TOTAL
MOTIVASI KRITIS

\begin{tabular}{|c|c|c|c|}
\hline \multirow{3}{*}{$\begin{array}{c}\text { TOTAL } \\
\text { MOTIVASI }\end{array}$} & $\begin{array}{l}\text { Pearson } \\
\text { Correlation }\end{array}$ & 1 & $0,218^{*}$ \\
\hline & $\begin{array}{l}\text { Sig. (2- } \\
\text { tailed) }\end{array}$ & & 0,047 \\
\hline & $\mathrm{N}$ & 84 & 84 \\
\hline \multirow{3}{*}{$\begin{array}{l}\text { TOTAL } \\
\text { KRITIS }\end{array}$} & $\begin{array}{l}\text { Pearson } \\
\text { Correlation }\end{array}$ & $0,218^{*}$ & 1 \\
\hline & $\begin{array}{l}\text { Sig. (2- } \\
\text { tailed) }\end{array}$ & 0,047 & \\
\hline & $\mathrm{N}$ & 84 & 84 \\
\hline
\end{tabular}

Koefisien korelasi sebesar 0,218 menunjukkan bahwa pola hubungan yang terbentuk adalah hubungan searah. Hal ini menunjukkan bahwa jika motivasi belajar yang dimiliki mahasiswa tinggi maka kemampuan berpikir kritis matematisnya juga tinggi. Namun apabila motivasi belajar mahasiswa rendah maka akan diikuti dengan rendahnya nilai kemampuan berpikir kritis matematis mahasiswa.

Analisis Perbedaan Pengaruh Tingkat Motivasi Belajar ditinjau dari Latar Belakang Jurusan (IPA, IPS dan Kejuruan) Terhadap Kemampuan Kritis Matematis

Analisis perbedaan pengaruh tingkat motivasi belajar ditinjau dari latar belakang jurusan (ipa, ips dan kejuruan) terhadap kemampuan kritis matematis berdasarkan uji beda atau kesamaan varian dengan menggunakan uji $\mathrm{F}$, maka ditemukan bahwa motivasi belajar ditinjau dari latar belakang pilihan jurusan (IPA, IPS dan Kejuruan) pada mata kuliah Struktur Aljabar II diperoleh signifikansi sebesar $0,273>0,05$, ini menunjukkan bahwa tidak terdapat perbedaan yang signifikan antara motivasi belajar baik Mahasiswa berlatar belakang jurusan IPA, IPS dan Kejuruan terhadap kemampuan berpikir kritismahasiswa pada mata kuliah Struktur Aljabar II.

Berdasarkan hasil $F$ hitung ditemukan bahwa Besarnya pengaruh motivasi belajar terhadap Kemampuan berpikir kritis mahasiswapada mata kuliah Struktur Aljabar II sebesar 48,297 sedangkan sisanya sebesar 51,703dipengaruhi oleh faktor-faktor lain.

\section{SIMPULAN}

Berdasarkan hasil penelitian, analisis data dan pembahasan yang telah dilakukan, maka dapat diambil kesimpulan yakni ditemukan pengaruh motivasi belajar mahasiswa terhadap kemampuan berpikir kritis matematis mahasiswa di STKIP Siliwangi Bandung pada Mata Kuliah Struktur Aljabar II dan besarnya pengaruh motivasi belajar terhadap Kemampuan 
berpikir kritis mahasiswa pada mata kuliah Struktur Aljabar II sebesar 48,297 sedangkan sisanya sebesar 51,703 dipengaruhi oleh faktor-faktor lain.

\section{DAFTAR PUSTAKA}

Depdiknas.(2002). UU No. 20 Tahun 2003 Tentang Sistem Pendidikan Nasional. Jakarta: Depdiknas

Fachrurazi.(2011). Penerapan Pembelajaran Berbasis Masalah untuk Meningkatkan Kemampuan Berpikir Kritis dan Komunikasi Matematis Siswa Sekolah Dasar. Jurnal UPI [online]. Vol 1, halaman 76-89. Tersedia:http://jurnal.upi.edu/file/8Fachrurazi.pdf [5 Oktober 2015]

Fisher,

A. (2001). CriticalThinkinginIntroduction. United Kingdom : CambridgeUniversity Press.

Hendrayana, A. (2008). Pengembangan Multimedia Interaktif Untuk Meningkatkan Kemampuan Berpikir Kritis dan Kreatif Siswa SMP Dalam Matematika. Tesis PPS UPI Bandung : Tidak Diterbitkan.

Mudrikah, A. (2006). Penggunaan Model Pembelajaran Konsep Untuk Meningkatkan Kemampuan Pemahaman Konsep matematik dan Keterampilan Berpikir Kritis Siswa SMA. Tesis PPS UPI Bandung : Tidak Diterbitkan.

Purwanto, M. Ngalin. 2002. Psikologi Pendidikan. Bandung: PT. Remaja Rosdakarya.

Runisah. (2008). Penggunaan SQ3R dalam Pembelajaran Matematika untuk Meningkatkan Kemampuan Berpikir Kritis Matematis Siswa SMA. Bandung.TesisSPs UPI. Bandung: Tidak Diterbitkan.

Ruseffendi, E.T.(2006). Pengantar Kepada Membantu Guru Mengembangkan Kompetensinya dalam pembelajaran matematika untuk meningkatkan CBSA. Bandung : Tarsito.
Sardiman, A.M. (2007).Interaksi dan Motivasi Belajar Mengajar. Jakarta: Raja Grafindo Persada

Splitter,L.J. (1991). CriticalThingking : What, Why, When, andHow.AustralianCouncil of Educational Research. 